\title{
Methyl 2-phenethynylcyclopropanecarboxylate
}

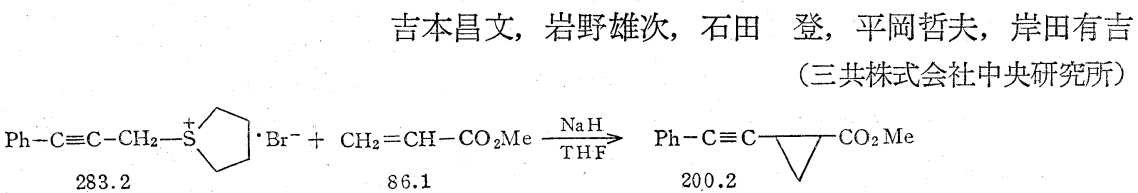

\section{I. 製 法 ${ }^{1)}$}

温度計，塩化カルシウム管，ガス導入管，およびかきまぜ機をつけた $5 l$ の四つロフラスコ（注意 1 ）に，tetramethylenephenylpropargylsulfonium bromide ${ }^{1 \mathrm{~b}}$ ) (注意 2 ) $113 \mathrm{~g}(0.400 \mathrm{~mol})$, methyl acrylate $68.9 \mathrm{~g}(0.800 \mathrm{ml})$, テトラヒドロフラン (THF) $3.0 l$ (注意 3 ) を入れ，水 $9.0 \mathrm{~m} l$ を加えて（注意 4 ）窒素を導入しながらかきまぜて食 塩を入れた氷浴上で $0 \sim 5^{\circ} \mathrm{C}$ に泠却する。 $50 \%$ 水素化ナトリウム $19.2 \mathrm{~g}(0.400 \mathrm{~mol})$ を 4,5 回に分けて約 1 時間で 加える(注意 5 )。そのさい温度が $5{ }^{\circ} \mathrm{C}$ 以下にさがったらつぎの分量を加え, $10^{\circ} \mathrm{C}$ を超えないようにする。加え終ったら 30 分間そのままかきまぜた後, 氷浴を取り去って 5 時間かきまぜる。反応液を $7 l$ の水水に投入し, 酢酸エチル $7 l$ を 用いて抽出・分液し有機層を食塩水 $3 l$ ずつで 2 回洗ってから硫酸マグネシウム $1.5 \mathrm{~kg}$ を用いて乾燥する。溶媒を留 去した後に減圧蒸留すれば無色油状物として methyl 2-phenethynylcyclopropanecarboxylate $60.2 \mathrm{~g}$ が得られる（注意 6 )。収率 $75.2 \%$, bp $110-112^{\circ} \mathrm{C} / 0.3 \mathrm{mmHg}$ 。

\section{耼. 注意事項}

（1）一つの口はセンをし水素化ナトリウムの投入口とする。

（2）本化合物の製法は文献?2にしたがって合成する。

(3) $\mathrm{LiAlH}_{4}$ あるいは $\mathrm{KOH}$ を加えて新しく蒸留したものを用いる。

（4）水の量は $0.3 \%$ が最適であり， $0.4 \%$ 以上交るいは $0.2 \%$ 以下では収率が下がる1b)。

（5） :げしく水素を発生するのでドラフト内で反応を行ならかあるいは発生水素を危険の無、場所澊く必要があ る。反応液は淡黄色になる。

（6）水素化ナトリウムに由来する少量の炭化水素が混入するが，シリカゲルを用いたドライカラムクロマト（ベン ゼンで展開) で精製できる。また本品はトランス体 90～92\%，シス体 8 10\% の混合物であり，精密なカラムクロマ トあるいはガスクロマトにより分離できる ${ }^{1 b}$ 。 $\mathrm{KOH}$ を $90 \% \mathrm{MeOH} に 5 \%$ とかした溶液中室温で加水分解して対応 するカルボン酸に導びくことができる。蒸留したエステルの混合物を加水分解しても $70 \%$ の収率で $100 \%$ トランス体 のカルボン酸が得られる。

\section{III. 性質}

bp $110 \sim 112^{\circ} \mathrm{C} / 0.3 \mathrm{mmHg}$ 。〔カルボン酸はトランス体 $\mathrm{mp} 90^{\circ} \mathrm{C}$ ，シス体 $\mathrm{mp} 85^{\circ} \mathrm{C}$ (ともにへキサンあるいはへプタ ンから再結晶) J。UV : $\lambda_{\max }^{\mathrm{EtOH}} 249 \mathrm{~nm}(\log \varepsilon=4.31) ; \mathrm{IR}: \nu_{\max }^{\mathrm{film}} 2235,1733 \mathrm{~cm}^{-1} ; \mathrm{NMR}: o \mathrm{ppm}$ in $\mathrm{CDCl}_{3} 1.1 \sim 1.6$ $(2 \mathrm{H}, \mathrm{m}), 1.9 \sim 2.2(2 \mathrm{H}, \mathrm{m}), 3.72(3 \mathrm{H}, \mathrm{s}), 7.3(5 \mathrm{H}, \mathrm{m}) ; \mathrm{Eu}(\mathrm{DPM})_{3}$ を加えて測定すると, 環上水素加一次解析 できる ${ }^{3)}$ 。

\section{IV. 本法の利点}

類似化合物は 1-phenyl-3-buten-1-yne にジアゾ䣷酸エステルを反応させても合成できるが1)，収率が悪くトランス : シス $=65: 35$ と選択性が低い。従来, 三重結合に隣接するイオウイリドは[2,3]-sigmatropic rearrangement 起す 2,4)ために三員環合成には適さなかったが，環状スルフィドを原料に用いて，この転位を最少限にすることができた。

\section{引用文献}

1a) M. Yoshimoto, N. Ishida, Y. Kishida, Chem. Pharm. Bull. (Tokyo) 19863 (1971)

b) idem, ibid. 202593 (1972)

2) A. Terada, Y. Kishida, Chem. Pharm. Bull. (Tokyo) 17966 (1969)

3) M. Yoshimoto, T. Hiraoka, H. Kuwano, Y. Kishida, Chem. Pharm. Bull. (Tokyo) 19849 (1971)

4) J.E. Baldwin, R.E.Hackler, D.P. Kelly, Chem. Commun. 19681083 